\title{
PV generation of Hydrogen for operational rawinsonde usage: design and economic analysis
}

\author{
A. Pettazzi ${ }^{1}$, C. M. Torres ${ }^{2}$, J. A. Souto ${ }^{1}$, P. Bello ${ }^{1,2}$ \\ ${ }^{1}$ Department of Chemical Engineering \\ ${ }^{2}$ Aula de Energías Renovables, School of Engineering \\ University of Santiago de Compostela \\ c/ Lope Gómez de Marzoa, s/n - Campus Sur, 15782 Santiago de Compostela \\ Phone Number: 981563100 Ext. 16770, e-mail: mrtepax@usc.es, carmenmari.torres@rai.usc.es, \\ jasouto@usc.es, eqpmbb@usc.es
}

\begin{abstract}
Operational meteorological rawinsonde balloons are usually filled by using Helium gas, provided by an external company. Alternatively, renewable energies may be used to generate Hydrogen for operational meteorological balloons usage. In this work, a Hydrogen plant to produce gas by electrolysis, with electricity generated by PV cells, is proposed and designed, to be used in an operational rawinsonde.

Taking into account both technical and legal conditions for solar energy exploitation in Spain, two technical configurations were considered and designed: (a) autonomous system, that is, electric power produced by the PV cells is used to feed the whole process of Hydrogen production; and, (b) connected system, that is, electric power produced by the PV cells is supplied to the Spanish Electric Network (REE) and, at the same time, Hydrogen is produced by electrolysis using energy provided by REE. Option (b) can be considered because of the economic benefits set by the Spanish Real Decreto 436/2004, as the energy is provided by REE at a lower price than the energy supplied by the PV cells.

In order to compare both options and the feasibility of the project, an economic analysis is also presented, including: investment evaluation, incomes and expenses analysis. Different sold and consumed power supply prices are considered as well as financial costs, and Helium gas savings. In addition, a feasibility study based on the general criteria of operation and installation, such as payback period, net actual value (NAV) and internal rate of return (ROI) is also presented.
\end{abstract}

\section{Introduction}

The development of technologies to enhance renewable energies is a priority target to sustainability. Reasons are different, mainly dealing with the solution of global problems, such as energy supply and carbon dioxide reduction [1]. According to this, the current trend is to make renewable energies more and more competitive with respect to the traditional ones.

Between renewable energies, solar resource is one of the most attractive since it can be used in either direct or indirect way, providing a wide range of energy generation, including Hydrogen [2]. Photovoltaic Hydrogen represents a renewable source of fuel and electricity; nowadays, production plants are operational all over the world. Moreover, there are installations to generate Hydrogen built in private houses that supply the energy required by the owners [3]. Some installations are also used to practical purposes, such as the filling of meteorological balloons [4].

One of the tasks carried on by MeteoGalicia, the Galician Weather Service (www.meteogalicia.es), is an operational rawinsonde that, twice a day, provides aloft observations of atmospheric parameters. Currently, balloons are filled with Helium provided by a company.

In this work, a plant to produce Hydrogen by water electrolysis, starting from electricity generated by PV panels, is designed. This plant would be placed in the School of Engineering at Santiago de Compostela (NW Spain), where the balloons are daily launched. In order to evaluate the feasibility of this project, two options were considered:

1. electric power produced by the PV cells is used to feed the whole process of production of Hydrogen (autonomous system).

2. electric power produced by the PV cells is supplied to the Spanish Electric Network (REE) (connected system), taking advantage of the economic benefits set by the Spanish Real Decreto 436/2004. At the same time, Hydrogen is produced by electrolysis using energy provided by the REE network, at a lower price than the supplied by the PV cells. 
The decision of undertaking a project with this characteristics has to be taken according to different factors. Some projects are carried out because of their social profitability, others for their environmental profitability, and many because of their election yield. But the feasibility of most of the projects uses to be determined by their financial profitability.

For this reason, both technical and economic issues are considered in this analysis. After presenting both technical solutions (including the specific problems related to the Hydrogen production and storage), investment budget, operating costs and exploitation incomes are evaluated. Then, the financial yield of the project is considered.

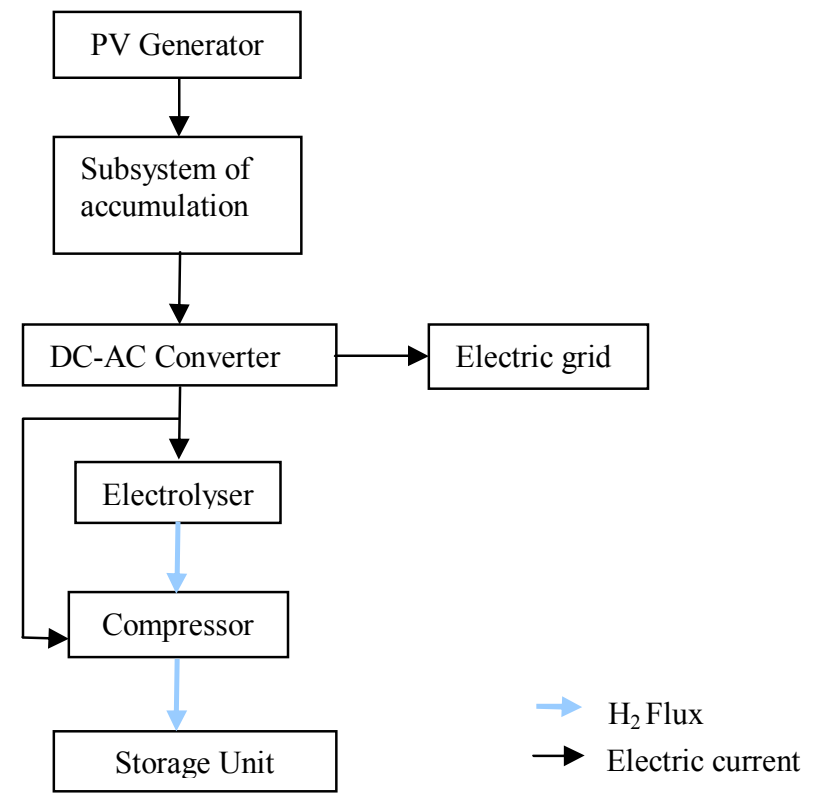

Fig 1-a. Diagram of the autonomous system

\section{A. Photovoltaic Generator}

For the technical design of this module, it is of primary importance the determination of the number $(N)$ of PV modules to be connected in serial and in parallel. The modules can be placed over the roofs and other available spaces of the School of Engineering. Selected model was Isofotón IS-150/12, which main features are described on Table I.

TABLE I - Main features of the selected PV modules

\begin{tabular}{|c|c|}
\hline \multicolumn{2}{|c|}{ Physical Features } \\
\hline Dimensions [mm] & $1590 \times 790 \times 39.5$ \\
\hline Weight [kg] & 14.4 \\
\hline Electrical Features (1000 & $W m-2 ; 25 \mathrm{C})$ \\
\hline Maximum power [Wp] & $150 \pm 5 \%$ \\
\hline Maximum power current [A] & 8.7 \\
\hline Maximum power voltage [V] & 17.3 \\
\hline Short circuit current [A] & 9.3 \\
\hline Open circuit voltage [V] & 21.6 \\
\hline
\end{tabular}

\section{Plant description}

Based on the work of Hollmuller [3] and considering the requirements of Hydrogen production and its frequency, the Hydrogen process is based in a home installation, as it is described in Hollmuller [3]. This kind of installations includes two main parts: a PV generator, DC-AC, water supply, and a electrolyser for Hydrogen production; compression and storage units, for Hydrogen storage. Every module is described in detail in this section.

Keeping in mind the two options described in section 1 , installations diagrams are shown on Fig. 1-a and Fig. 1-b. Since the design is made for the worst month, in the autonomous system (Fig. 1-a) the exceeding energy produced by the photovoltaic generator is sold to the REE.

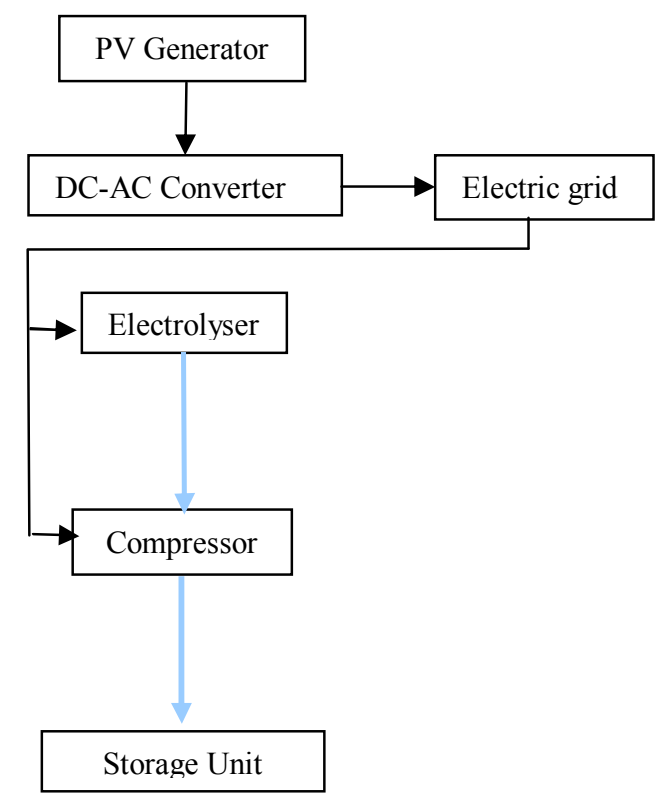

Fig. 1-b. Diagram of the connected system

\section{B. Accumulation subsystem}

Since commercial devices used to produce and store Hydrogen work in a $\mathrm{AC}$ regime, it is necessary to provide them a constant power value. This is achieved by setting a battery array, load regulators and $\mathrm{AC} / \mathrm{DC}$ converters.

For this work, $\mathrm{Pb}$-acid tubular batteries from Isofotón were selected. Model 2.AT.4505 from Isofotón was considered appropriate. Table II contains its main features. The state of the batteries is regulated by the controller Xantrex C40, while the DC-AC converter, that connects the system to the grid, is the Xantrex SW4548E.

TABLE II - Main features of the batteries selected in this work

\begin{tabular}{|c|c|}
\hline \multicolumn{2}{|c|}{ Physical Features } \\
\hline Dimensions [mm] & 576x212x813 \\
\hline Weight [kg] & 239 \\
\hline \multicolumn{2}{|c|}{ Electrical Features } \\
\hline Voltage [V] & 2 \\
\hline Capacity10h@25 C [Ah] & 3360 \\
\hline Capacity100h@25 C [Ah] & 4505 \\
\hline
\end{tabular}




\section{Electrolyser, compression and storage units}

Following the work of Hollmuller, it has been taken into account an electrolyser with a flow of $2 \mathrm{Nm}^{3} /$ hour released with a pressure of 2 bar. The module considered for the present work has a working temperature of $50 \mathrm{C}$, employs $\mathrm{KOH}$ as electrolyte and should consume $9.5 \mathrm{~kW}$ at full regime. In order to keeping down the costs, the electrolyser should be customised [6].

Hydrogen produced by the electrolyser is then compressed to 29 bar by the compressor Corken-D191. Power consumption is $0.125 \mathrm{kWh} / 0.59 \mathrm{Nm}^{3}$. The process takes a few minutes to complete.

Hydrogen is then stored in a stack of metal cylinders filled with a hydrogen absorbing alloy (derivative of $\mathrm{TiMn}_{2}$ ). In order to accomplish the needs of $\mathrm{H}_{2}$ even in days characterized by low levels of irradiation (see following sections), it has been considered appropriate a volume of $90 \mathrm{~L}$. Because of legal security rules, storage unit is enclosed in a isolated room that includes the electrolyser.

\section{System design}

\section{A. Estimation of the Hydrogen volume requirements}

For the current operational rawinsonde, two launches per day are performed with balloons filled with Helium. The gas volume needed to fill one balloon, in order to achieve an aloft rate of $300 \mathrm{~ms}^{-1}$, is determined by a reference weight of $2.5 \mathrm{~kg}$; when the balloon begins to lift the weight, there is gas enough to launch the balloon.

Therefore, the Hydrogen volume that is necessary for a launch can be estimated by means of the Archimedes' Principle:

$$
2.5 \cdot g+\rho_{H 2 O} \cdot V \cdot g=\rho_{\text {air }} \cdot V \cdot g
$$

where $g$ is the gravity's acceleration, $\rho$ is the air density (in standard conditions), and $V$ is the volume of the balloon (filled of Hydrogen). From equation (1) a value of $2.31 \mathrm{~m}^{3}$ of Hydrogen volume is obtained; therefore, the daily volume of hydrogen that has to be generated is $V=4.62 \mathrm{~m}^{3}$. Considering the efficiency of the electrolyser, the value of $V$ may be rounded to $5 \mathrm{~m}^{3}$.

\section{B. Daily mean irradiation and determination of the worst month}

As this process is planned to be installed at the School of Engineering in Santiago de Compostela, solar irradiation measurements at this location were considered. Observations of horizontal surface irradiation collected by the EOAS jointly automatic weather station [5], located near the School, were collected. Measurements provided by a Ph-Schenk class A pyranometer, from June 2005 to June 2006, are reported in Table III. Besides the monthly daily means of irradiance, it also includes the derived [7] mean values of monthly mean optimal inclination, and the corresponding values of irradiation.
The PV system is designed to accomplish the energy demand along the worst month of the year, as the month where the ratio between the daily mean irradiation and the energy demand is the lowest one. It can be noticed that the worst month is March 2006, mainly due to the high number of rainy days recorded at this period. Anyway, a longer data set in the location (not yet available) would allow a better design of the PV equipment.

TABLE III - Mean values of irradiation in Santiago (June 2005 - June 2006)

\begin{tabular}{|c|c|c|c|}
\hline Month & $\begin{array}{c}\text { Daily Irradiation } \\
\text { monthly averaged } \\
\text { over horizontal } \\
\text { surface }\left(\mathrm{kWh} / \mathrm{m}^{2}\right)\end{array}$ & $\begin{array}{c}\text { Mean } \\
\text { optimal } \\
\text { slope } \\
(\text { degrees })\end{array}$ & $\begin{array}{c}\text { Daily Irradiation } \\
\text { monthly averaged } \\
\text { optimal slope } \\
\left(\mathrm{kWh} / \mathrm{m}^{2}\right)\end{array}$ \\
\hline Jan & 2.11 & 63.75 & 4.77 \\
\hline Feb & 2.70 & 56.27 & 4.86 \\
\hline Mar & 2.64 & 45.36 & 3.75 \\
\hline Abr & 5.07 & 33.47 & 6.08 \\
\hline May & 6.01 & 24.13 & 6.58 \\
\hline Jun & 5.18 & 19.81 & 5.50 \\
\hline Jul & 6.06 & 21.71 & 6.52 \\
\hline Aug & 6.10 & 29.46 & 7.01 \\
\hline Sep & 4.715 & 40.73 & 6.22 \\
\hline Oct & 3.99 & 52.58 & 6.57 \\
\hline Nov & 2.16 & 61.83 & 4.58 \\
\hline Dic & 1.82 & 65.95 & 4.47 \\
\hline
\end{tabular}

\section{Design of the autonomous system}

1) Determination of the daily electric energy to supply. As it was shown in section 2, every module requires AC. On Table IV are reported the receiving devices, together with the estimated daily consumption of energy. The average total energy demanded by the whole system is given by equation (2),

$$
E_{d e m}=\left(100+F_{S}\right) \cdot \frac{E_{A C}}{\eta_{D C-A C}}
$$

where $\eta_{D C-A C}$ is the efficiency of the converter, assumed to be $90 \%$, and $E_{A C}$ is the total energy demanded by all the devices that work in alternate current. $F_{S}$ represents the security factor that accounts for possible energy losses in the connections. $F_{S}$ has been estimated to be $15 \%$ [8]. According to equation (2), $E_{d e m}=31.94 \mathrm{kWh}$ per day.

TABLE IV - Daily mean energy requested by the devices that work in $\mathrm{AC}$

\begin{tabular}{|c|c|c|c|}
\hline Device & Power $(\mathrm{kW})$ & $\begin{array}{c}\text { Hours of } \\
\text { functioning }\end{array}$ & $\begin{array}{c}\text { Daily energy } \\
\text { request } \\
(\mathrm{kWh})\end{array}$ \\
\hline Electrolyser & 9.5 & 2,5 & 23.75 \\
\hline Compressor & 3.2 & - & $1.25[3]$ \\
\hline \multicolumn{2}{|c|}{ Total consumption $(\mathrm{kWh})$} & 25 \\
\hline
\end{tabular}


2) Determination of the number of $P V$ modules and its connection. In this project will be installed PV modules Isofotón IS-150/12, which features are described in Table I. The efficiency of each module is $\eta_{\text {mod }}=11.9 \%$, given by the ratio between the peak power and the nominal irradiance captured by the panel.

Considering the optimal irradiation $G_{\text {opt }}$ in the worst month (Table III), the average daily energy supplied by the PV generator, will be,

$$
E_{p}=\eta_{\text {mod }} \cdot G_{\text {opt }} \cdot S \cdot N
$$

where $S$ is the area of each PV module and $N$ is the number of panels of the generator.

As the real conditions of work of the PV generator may not match with the nominal ones, a correction factor, $C_{f}$, must be applied, that depends on the site and its climatologic conditions. A typical value of $C_{f}$ for the North of Spain is 1.3 [9]. Of course, generated energy has to be equal to the demanded energy estimated before.

Thus, the total number of PV modules has to be $N=76$, connected 4 in serial and 19 in parallel.

3) Design of the accumulation subsystem. In this work it has been chosen $\mathrm{Pb}$-acid batteries, with a maximum depth of discharge $P_{D, \max }=0.7$ and a maximum depth of daily discharge $P_{D, \text { daily }}=0.2$. From the climatologic data contained in the database of meteogalicia, it has been established that the number of days of autonomy of the batteries system has to be $N_{D}=7$. The capacity needed by the accumulation system, $C^{\prime}{ }_{T}$, is given by (4):

$$
C_{T}{ }_{T}=1.1\left(N_{D} \cdot E_{\text {elec, } \max }\right) /\left(P_{D, \max } \cdot V_{T, a c c}\right)
$$

where $E_{\text {elec, } \max }$ is the mean daily energy needed by the system during the worst month and $V_{T, a c c}$ represents the operational voltage of the subsystem. The value of $C_{T}^{\prime}=7319.6$ Ah justifies the choice of the batteries described in Table II. Consequently, the number of accumulators connected in series and parallel will be, respectively, $N_{S, a c c}=24$ and $N_{P, a c c}=2$, providing a total number $N_{a c c}=48$.

4) Design of the regulation subsystem. Regardless of the specific features of a particular regulator, it must be specified the nominal values of the following parameters: the nominal voltage $V_{\text {reg, }}$, the nominal intensities of the switch between PV modules and batteries $\left(\mathrm{I}_{\text {reg gen-acc }}\right)$ and between batteries and the devices connected ( $\left.\mathrm{I}_{\text {acc dev }}\right)$. These parameters, for the present work, have the following values:

$$
\begin{aligned}
& \mathrm{V}_{\text {reg }}=48 \mathrm{~V} \\
& \mathrm{I}_{\text {reg gen-acc }}=220.9 \mathrm{~A} \\
& \mathrm{I}_{\text {acc dev }}=142.01 \mathrm{~A}
\end{aligned}
$$

5) Shadow calculation. The presence of shadows plays an important role in determining the area of the PV generator. Shadows should be avoided to eliminate losses by dispersion and the so-called "warm point" problem. The effect of shadows of the PV panels has been evaluated for the winter solstice, as it is shown on Fig. 2. The value of the shadow has been increased, multiplying it by 1.25 . Consequently, the area occupied by the photovoltaic generator is $A=296.6 \mathrm{~m}^{2}$.

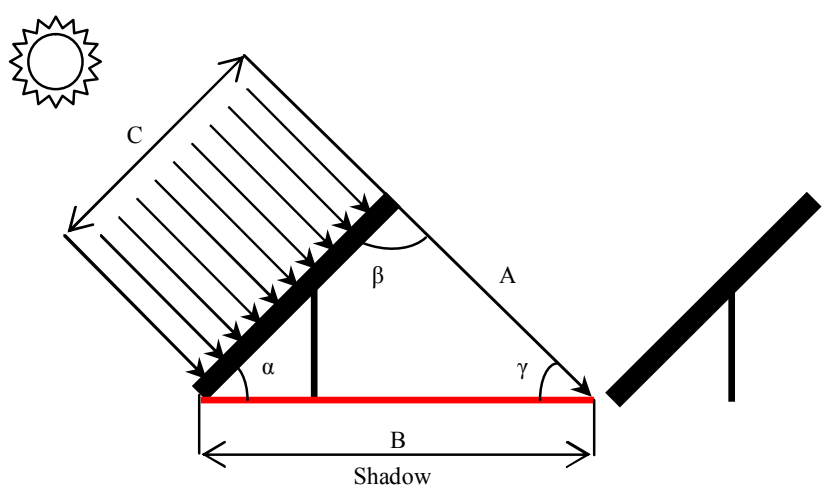

Fig.2. Estimation of the shadows of PV panels

\section{Design of the connected system}

This configuration differs from the autonomous system because all the PV electric power is sold to REE, obtaining a reimbursement. On the other hand, the energy needed by the devices to produce Hydrogen is taken from REE. This procedure gives a profit, set by the Spanish Real Decreto 436/2004 [11], that may write off the original investment.

Following Fig. 1-b, and assuming a converter efficiency of $90 \%$, the energy demanded to assure the production of Hydrogen is $E_{d e m}=31.9 \mathrm{kWh} /$ day. Thus, the number of PV modules that constitute the generator is $N=76$, connected in serial (4) and parallel (19).

\section{Economical Analysis}

In this section an economic study of both proposed installations, autonomous system and connected system, is shown. From the results of this analysis, a decision about the feasible of both systems (which are technically similar) can be obtained, in order to select the best solution. In addition, a general evaluation about the legal conditions of both PV autonomous and connected systems in Spain can be achieved.

\section{A. Autonomous system}

1) Investment. As this economic study is treated from the point of view of a design selection, estimations of the costs values of the different equipments were considered (Table V), in order to obtain a coarse estimation of the global investment.

2) Investment funding. According to the IDAE [11] subsidy plan (started on July 2006), up to $100 \%$ of the initial costs of autonomous photovoltaic installations can be financed, including: photovoltaic collector, storage batteries, converters, regulators, wiring and the 
associated civil engineering. This means the $77.5 \%$ of the total investment, with the conditions shown on Table VI.

TABLE V - Costs Investment for the autonomous system.

\begin{tabular}{|c|c|c|}
\hline Device & Cost (Euros) & $\begin{array}{c}\text { \%o of total } \\
\text { investment }\end{array}$ \\
\hline PV panels & 43300 & 36.0 \\
\hline Electric wiring & 3000 & 0.5 \\
\hline Battery array & 44000 & 36.6 \\
\hline $\begin{array}{c}\text { Metallic structure and } \\
\text { upright }\end{array}$ & 2500 & 2.08 \\
\hline AC/DC converter & 2850 & 2.4 \\
\hline Electrolytic unit & 6000 & 5 \\
\hline Storage system & 21000 & 17.46 \\
\hline Total & 120250 & 100 \\
\hline \multicolumn{2}{|c}{}
\end{tabular}

TABLE VI - Financial conditions of the autonomous system investment (IDAE)

\begin{tabular}{|c|c|}
\hline Own funds & $22.5 \%$ \\
\hline Financed capital & $77.5 \%$ \\
\hline Loan deadline & 11 years \\
\hline Interest rate & Euribor +0.30 \\
\hline
\end{tabular}

3) Exploitation costs. In this section, operation costs are considered. For the autonomous system, the costs of the water supply are calculated taking into account the water (tap) requirements of the electrolyser, which is $255501 /$ year.

Besides, maintenance cost is considered, as usual (10\% of the investment). In addition, because of the low cost of the PV panels' maintenance, their cost is excluded from the maintenance estimation.

4) Operating incomes. For the autonomous system, incomes can be evaluated by the Helium saving. Thus, taking into account the expenses in the last year due to the Helium purchase, an annual saving of $1876 € /$ year is obtained. For annual saving the update, an IPC of $3.9 \%$ is considered. Apart from this, the installation has the possibility of sell the excess of the produced energy to the REE network. According to a monthly study for the energy production, an estimation for the annual excess of energy is $6200 \mathrm{kWh}$. The sale price is $0,44 € / \mathrm{kWh}$, and for the following years an IPC of $3.9 \%$ is considered.

5) Cash flow calculation. In this case the profit is calculated by means of the yearly cash-flows. The gross cash-flow is determined with the Helium saving, which will be considered as an income, and the electricity sale minus the exploitation costs, and also the financial costs applied to the $77.5 \%$ of the total investment, with an interest rate of $3,93 \%$. At the same time, the taxes are supposed at the $35 \%$ of net margin.

6) Analysis of the economic feasibility. In this section some economic criteria that show the profitability of the project will be presented [12]. From the analysis of the incomes and expenses the profit value for the first years of operation is negative, as a consequence of the high exploitation costs. The payback period needed to recover the initial outlay is evaluated from the cash-flows, giving as result a number of years higher than the expected lifetime of the project. From this point of view the operation of the autonomous system will not be able to recover the initial investment, thus the project is not profitable. Therefore to continue with an analysis in depth is not necessary.

\section{B. Connected system}

1) Investment. In this case the batteries are not necessary. So the initial outlay for connected systems, as in general, tends to be lower than in autonomous ones.

TABLE VII - Investment costs of connected system.

\begin{tabular}{|c|c|c|}
\hline Device & Cost (Euros) & $\begin{array}{c}\text { \% of total } \\
\text { investment }\end{array}$ \\
\hline PV panels & 43320 & 59 \\
\hline Electric wiring & 3000 & 0.8 \\
\hline $\begin{array}{c}\text { Metallic structure and } \\
\text { upright }\end{array}$ & 2500 & 3.4 \\
\hline AC/DC converter & 2850 & 8.1 \\
\hline Electrolytic unit & 6000 & 8.2 \\
\hline Storage system & 21000 & 24.5 \\
\hline Total & 73420 & 100 \\
\hline
\end{tabular}

2) Investment funding. There are not grants for the investment of PV installations which supply electric power to the REE, therefore an investment funding plan is proposed on table VIII.

TABLE VIII - Financial conditions of the connected system investment (market)

\begin{tabular}{|c|c|}
\hline \multicolumn{2}{|c|}{ Installation investment } \\
\hline Owner funds & $30 \%$ \\
\hline Financed capital & $70 \%$ \\
\hline Loan deadline & 11 years \\
\hline Interest rate & 7.23 \\
\hline
\end{tabular}

3) Exploitation costs. In the case of the connected system, the costs of supplies come from both the use of water to produce Hydrogen in the electrolytic unit (as in the autonomous case) and the supplied electric energy provided by REE.

The annual cost of the supplied energy is calculated taking into account that the foreseeable purchase price for 2007 is $0.05 € / \mathrm{kWh}$, that will be increased every year ahead of the IPC, initially a $1 \%$ is assumed until a $1.5 \%$ in 25 years.

In addition, the maintenance cost must be considered, as usual ( $10 \%$ of the investment). Again, because of the low cost maintenance of the PV panels, this module is not included in the maintenance.

Apart from the financial cost calculated with an interest rate of $7.23 \%$, straight line depreciation is considered during 20 years.

4) Operating incomes. In this case, incomes can be evaluated by both the Helium saving and the sale of the 
electric energy produced by the PV system to the REE. Helium annual profit is the same as in the autonomous system, so electric energy sale profit can be added directly.

According to the Spanish Real Decreto 436/2004 [10], which establishes for Spain the methodology for the updating and systematization of the legal and economic regime of electric power production activity in special regime, the sale price of the produced $\mathrm{kWh}$ is 0,44038 $€ / \mathrm{kWh}$, and for the following years an IPC of $3.9 \%$ is considered.
5) Cash flow calculation.. The gross cash-flow is determined with the combination of the Helium saving and electricity sale, which will be considered as an income, minus the exploitation costs and also the financial costs applied to the $50 \%$ of the total investment, with an interest rate of $7.23 \%$.

Net cash-flow is calculated taking the taxes away from the gross cash-flow. At the same time the taxes are estimated at the $35 \%$ of the subtraction between the incomes and expenses of the exploitation. Results of the annual balance are presented in table IX, considering an expected lifetime of the project of 20 years.

TABLE IX - Cash-flows for the connected system.

\begin{tabular}{|c|c|c|c|c|c|c|c|c|c|c|}
\hline Year & 1 & 2 & 3 & 4 & 5 & 6 & 7 & 8 & 9 & 10 \\
\hline Incomes & 7019.64 & 7293.40 & 7577.85 & 7873.38 & 8180.45 & 8499.48 & 8830.96 & 9175.37 & 9533.21 & 990500 \\
\hline \multirow{3}{*}{$\begin{array}{c}\text { Expenses: } \\
\text { Operating } \\
\text { Financial } \\
\text { Total }\end{array}$} & 1516.95 & 1539.73 & 1563.39 & 1587.98 & 1613.52 & 1640.07 & 1667.64 & 1696.30 & 1726.07 & 1757.00 \\
\hline & 1857.89 & 1857.89 & 2171.56 & 1930.28 & 1688.99 & 1447.71 & 1206.42 & 965.14 & 723.85 & 482.57 \\
\hline & 3374.84 & 3397.62 & 3734.95 & 3518.26 & 3302.52 & 3087.77 & 2874.07 & 2661.44 & 2449.92 & 2239.57 \\
\hline $\begin{array}{c}\text { Net } \\
\text { margin }\end{array}$ & 5502.69 & 5753.68 & 6014.46 & 6285.41 & 6566.92 & 6859.42 & 7163.32 & 7479.07 & 7807.14 & 8148,01 \\
\hline GrossCF & 3644.80 & 3895.79 & 3842.89 & 4355.13 & 4877.93 & 5411.71 & 5956.89 & 6513.93 & 7083.29 & 7665.44 \\
\hline Net CF & 1718.5 & 3032.73 & 2940.72 & 3412.32 & 3892.89 & 4382.80 & 4882.40 & 5392.07 & 5912.22 & 6443.24 \\
\hline Year & 11 & 12 & 13 & 14 & 15 & 16 & 17 & 18 & 19 & 20 \\
\hline Incomes & 10291.30 & 10692.66 & 11109.67 & 11542.95 & 11993.13 & 12460.86 & 12946.83 & 13451.76 & 13976.38 & 14521.46 \\
\hline \multirow{3}{*}{$\begin{array}{l}\text { Expenses } \\
\text { Operating } \\
\text { Financial } \\
\text { Total }\end{array}$} & 1789.14 & 1822.53 & 1857.22 & 1893.27 & 1930.72 & 1969.63 & 2010.06 & 2052.07 & 295.72 & 2141.06 \\
\hline & 241.28 & 0.00 & 0.00 & 0.00 & 0.00 & 0.00 & 0.00 & 0.00 & 0.00 & 0.00 \\
\hline & 2030.42 & 1822.53 & 1857.22 & 1893.27 & 1930.72 & 1969.63 & 2010.06 & 2052.07 & 2095.72 & 2141.06 \\
\hline $\begin{array}{l}\text { Net } \\
\text { margin }\end{array}$ & 8502.16 & 8870.13 & 9252.45 & 9649.68 & 10062.41 & 10491.23 & 10936.77 & 11399.69 & 11880.66 & 12380.39 \\
\hline GrossCF & 8260.88 & 8870.13 & 9252.45 & 9649.68 & 10062.41 & 10491.23 & 10936.77 & 11399.69 & 11880.66 & 12380.39 \\
\hline Net CF & 6985.55 & 75396.1 & 7864.58 & 8202.23 & 8553.05 & 8917.54 & 9296.25 & 9689.73 & 10098.56 & 10523.33 \\
\hline
\end{tabular}

6) Analysis of the economic feasibility. In this section some economic criteria that show the profitability of the project will be presented. First of all, the payback period needed to recover the initial outlay is evaluated from the cash-flows, giving between 9 and 10 years.

Second, the net actual value (NAV), as the overall updated inlets and outlets of the capital, is calculated by equation (4),

$$
N A V=-A+\sum_{i=0}^{n} q_{i} \cdot(1+k)^{-i}
$$

where $\mathrm{A}$ is the initial investment, $q_{i}$ is the cash-flow at the end of the year $i$, and $k$ is the updating rate, that takes the value of $10 \%$.

The resulting NAV has to be positive for a profitable project. Considering 20 years of operation, a NAV of $6877 €$ is obtained for the connected system.

On the other hand, a project is considered profitable when the internal rate of return (ROI) is higher than the normal interest rate in the capital market. It is calculated finding the value $r$ in equation (4) for NAV equal to zero.
As it is shown on Figure 3, according to the ROI the connected installation is profitable, so it represents a

lower risk for the investment than the autonomous installation. Moreover, the time needed to recover the initial outlay is shorter and the NAV is positive, so the investment in the connected case produces profit in the same year of operation.

TABLE X - Economic feasibility results, connected system.

\begin{tabular}{|c|c|c|}
\hline Criteria & Value & Analysis \\
\hline Payback & $9-10$ years & Favorable \\
\hline NAV & 6877 Euros & Favorable \\
\hline ROI & 0.118 & Favorable \\
\hline
\end{tabular}

\section{Conclusions}

A technical and economical evaluation of two options for a sustainable filling with Hydrogen of operational rawinsonde balloons, using PV energy and a electrolytic module, are presented. The first one is an autonomous system, which applies the PV energy directly to the Hydrogen production; the second one is a connected system, that provides the PV power to REE and collect 
the electricity for Hydrogen production from the electric company.

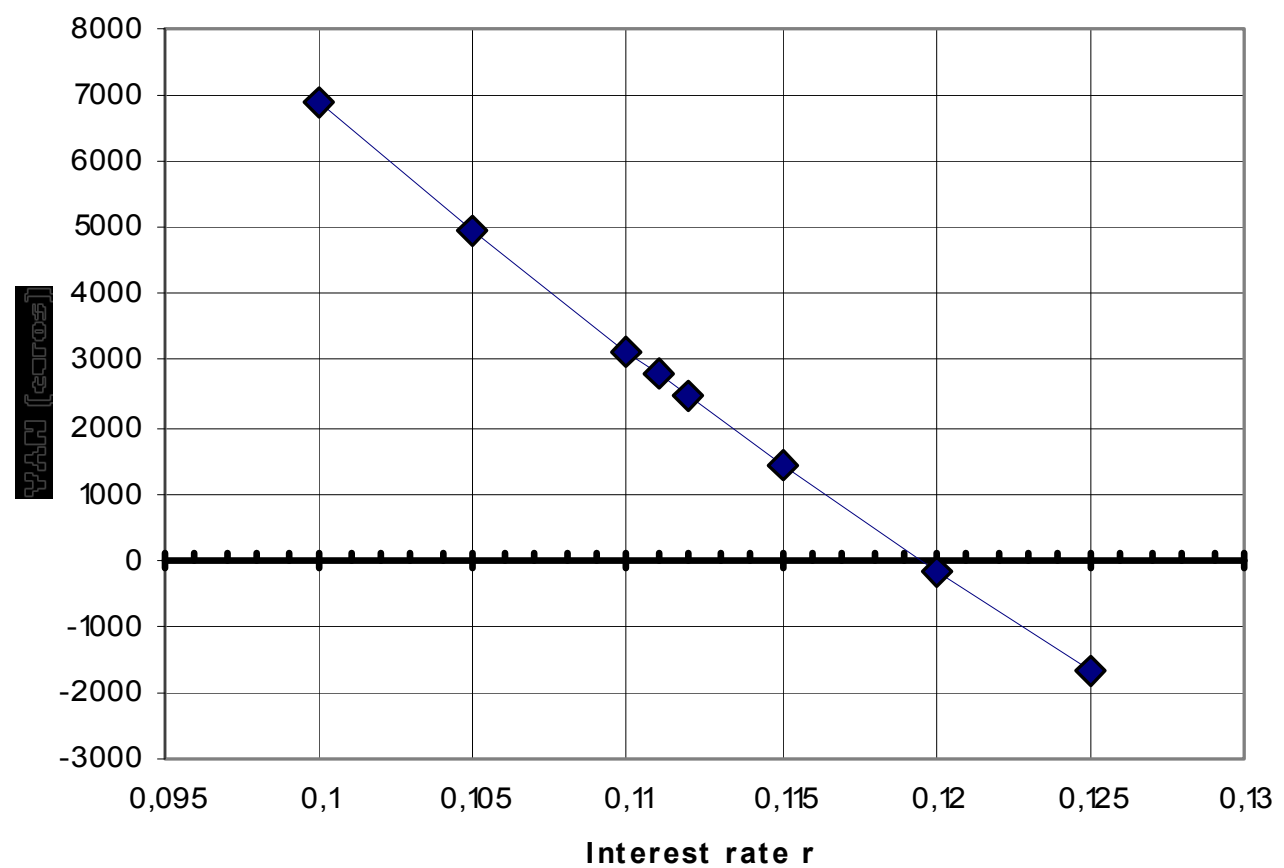

Figure 3. ROI for the connected system.

Technically, both solutions are feasible to be installed at the School of Engineering at Santiago de Compostela (where an operational rawinsonde is currently installed running with Helium). However, economically only the connected system is favorable, because of its lower investment and the price advantages of the PV production supplied to REE.

Therefore, from the feasibility study of both installations, the connected system is presented as the best option. One of the reasons is the large difference between the initial outlays of both installations in our case of study, due to the necessity of an electric storage system that allows the autonomy for the autonomous system. At the same time, the high investment derived in high maintenance costs and therefore, in a high exploitation values.

On the other hand, the connected system shows a good economic behavior from the point of view of the usual economic criteria. As the investment in this case is higher than in the general connected systems because of the equipment for hydrogen production, the payback period is a little longer as it is usual. The positive value for the VAN indicates that the investment in the project produces higher excesses than if this initial outlay was invested with an interest of $10 \%$.

The autonomous system takes advantage of the grants from IDAE, in order to reduce the capital risk. However, the best economic results are obtained by the connected system, taking advantage of the Spanish Real Decreto $436 / 2004$, with a higher profit derived from the difference between the PV price supplied to REE and the normal electric supply price paid to the electric company. Therefore, in this case the autonomous system suffer the disadvantage of the Spanish legal conditions of electric production and supplying, respect to the PV production.

\section{Acknowledgements}

Helpful suggestions from $\operatorname{Prof}^{a}$ A. Lopez-Aguera, about PV system and batteries systems, and Prof. M. Bao, about electrolyser, are acknowledged.

Technical data for the selection of PV cells and batteries were provided by Isofoton.

\section{References}

[1] Comisión de las Comunidades Europeas. COM 105 final. Libro Verde: Estrategia europea para una energía sostenible, competitiva y segura. SEC (2006) 317. Bruxelles, 2006.

[2] Berg, Raven. Environment. Wiley, 5th Edition, 2006.

[3] P. Hollmuller, J. Joubert, B. Lachal, K. Yvon, "Evaluation of a $5 \mathrm{kWp}$ photovoltaic hydrogen production and storage installation for a residential home in Switzerland". International Journal of Hydrogen Energy, 25, 97-109, 2000

[4] HYDROSOL: Production solaire d'hydrogéne, ISM payerne. NEFF project No 596; Zwischenbericht Mai, NEFF Pfluggässlein 2, CH-4001 Basel;EWI AG, CH-8034 Zürich 1995

[5] A. Pettazzi, J. A. Souto, S. Salsón, V. Pérez Muñuzuri, "EOAS, a shared joint atmospheric observation site of meteogalicia". In Proc IV International Conference on Experiences with Automatic Weather Stations. Lisbon, 24-26 may 2006

[6] Prof. Manuel Bao Iglesias (University of Santiago de Compostela), personal communication, 2007

[7] M. Iqbal, “ An introduction to solar radiation”. Academic Press, San Diego (CA) (1984).

[8] M. Ibáñez, J. I. Rosell, J. R. Rosell, “Tecnología Solar”. Ediciones Mundi-Prensa (2005). 
[9] E. Lorenzo, "Electricidad Solar - Ingeniería de los sistemas fotovoltaicos". Instituto de energía solar, Universidad Politécnica de Madrid, Madrid (1994)

[10] Real Decreto 436/2004, de 12 de marzo, "Por el que se establece la metodología para la actualización y sistematización del régimen jurídico y económico de la actividad de producción de energía eléctrica en régimen especial", Ministerio de Economía, BOE n.75 del 27 de Marzo de 2004.

[11] www.idae.es, Instituto para la Diversificación y Ahorro de la Energía.

[12] Eliseo Gómez-Senent Martínez, [et. al.], "Cuadernos de Ingeniería de Proyectos I: diseño básico (anteproyecto) de plantas industriales". Serv. de publicaciones Universidad Politécnica de Valencia, 1997. 